\title{
ANALISIS KELAYAKAN BISNIS PEMBUKAAN CABANG BARU RUMAH MAKAN VEGETARIAN
}

\author{
Andre Setiawan \\ Magister Manajemen, Universitas Katolik Parahyangan \\ Email: andre_zhao@yahoo.com
}

Submitted: Jan 17, 2018; Reviewed: Feb 9, 2018; Accepted: Mar 27, 2018

\begin{abstract}
This research proposed a performance management model based on existing theories, the concept to be developed using qualitative methods. The purpose of this paper is to find the model of performance management system with benchmarking and balanced scorecard approach. The challenge of this research is the implementation of this design model is still a few companies in Indonesia who can apply it. The final implication of this research is to provide a complex model of performance management system for companies that need and will implement it, as well as relevant for practitioners and academics, as it clarifies existing knowledge and provides a platform for further research.
\end{abstract}

Keywords: Performance Management, Performance Measurement, Benchmarking, Balanced Scorecard, KPI

\section{PENDAHULUAN}

Pesatnya perkembangan dalam berbagai bidang pada saat ini mengakibatkan munculnya perubahan gaya hidup dalam masyarakat. Mulai dari kebutuhan pokok, seperti: sandang, pangan dan papan hingga kebutuhan tersier telah banyak berubah seiring dengan perkembangan jaman. Perubahan akan kebutuhan-kebutuhan tersebut belum sepenuhnya dapat terpenuhi, hal ini disebabkan karena kurangnya atau bahkan belum terdapatnya produsen yang memproduksi kebutuhan-kebutuhan tersebut. Kebutuhan primer hingga tersier di masyarakan menjadi peluang bagi pelaku bisnis untuk membukan usaha sendiri dalam upaya memenuhi kebutuhan masyarakat tersebut. Peluang tersebut memang sangat menggiurkan bagi para pelaku bisnis tetapi terdapat beberapa kendala dalam mendirikan sebuah usaha yang berkompetisi di dunia bisnis yang penuh dengan persaingan. Salah satunya adalah sulitnya memperkirakan besar atau kecilnya risiko usaha yang dijalankan, banyak usaha yang telah gulung tikar sebelum mereka memperoleh keuntungan ataupun sekadar balik modal. Oleh karena itu penting untuk dilakukan analisis kelayakan bisnis sebelum membuka suatu usaha. Hal ini bertujuan agar pemilik usaha dapat mengetahui dan mengantisipasi risiko yang terdapat pada usaha yang dijalankan, memudahkan perencanaan usaha, sampai dengan keputusan apakah layak atau tidaknya usaha tersebut dijalankan.

Sebagai salah satu kebutuhan pokok, kebutuhan akan pangan tidak dapat dipandang sebelah mata lagi. Perkembangan ilmu pengetahuan dan teknologi yang pesat menjadikan kebutuhan pangan turut berkembang seiring dengan berjalannya waktu. Banyaknya makanan yang mengandung bahan pengawet, bahan pewarna, bahan penyedap dan zat-zat kimia lain yang tidak boleh dikonsumsi mulai memaksa masyarakat untuk teliti dan cermat dalam mengkonsumsi makanan. Penggunaan formalin, boraks, serta rhodamine dalam makanan sudah banyak beredar, mulai dari jajanan pasar hingga makanan di restoran. Efek dari mengkonsumsi zat-zat kimia tersebut memang tidak terasa saat itu juga tetapi efeknya baru dapat dirasakan dalam jangka panjang. Pengkonsumsian zat-zat tersebut dalam jangka panjang dapat mengakibatkan gangguan pencernaan, gangguan ginjal, kanker dan bahkan dapat menyebabkan kematian.

Kota Bandung mengalami perkembangan industri kuliner yang cukup pesat. Hal ini dapat dilihat dari banyaknya pelaku bisnis yang 
membuka usaha kuliner baru di kota Bandung. Peningkatan jumlah penduduk kota Bandung yang berasal dari berbagai daerah tiap tahunnya memicu para pelaku bisnis untuk membuka usaha kuliner dengan menu dari berbagai daerah. Alasan lain para pelaku bisnis membuka usaha kuliner di kota ini adalah tuntutan gaya hidup masyarakatnya. Gaya hidup masyarakat kota Bandung yang telah modern, menginginkan kepraktisan serta telah sadar akan pentingnya nilai kesehatan terutama dari asupan makanan yang dikonsumsinya. Seiring dengan perkembangan jaman, hal ini berdampak pada semakin meningkatnya juga taraf hidup masyarakat serta kebutuhan hidup manusia, terutama dalam bidang kuliner. Pada situasi seperti ini, menuntut kejelian para pelaku usaha bisnis untuk melihat potensi yang ada dalam membangun suatu usaha bisnis di bidang kuliner. Salah satu usaha dalam bidang kuliner adalah restoran vegetarian.

Dalam analisis kelayakan bisnis terdapat beberapa aspek yang menjadi pertimbangan dalam memulai usaha baru seperti aspek pasar, aspek pemasaran, aspek teknis, aspek keuangan, aspek SDM, aspek lingkungan dan aspek hukum. Dengan pertimbangan aspek-aspek tersebut, pada akhirnya dapat disimpulkan apakah suatu usaha tersebut layak untuk dijalankan atau sebaiknya usaha tersebut tidak dijalankan. Analisis kelayakan bisnis tidak hanya terbatas pada pendirian usaha baru, tetapi dapat juga dilakukan pada pembukaan cabang baru atau pembelian usaha yang sudah berjalan sebelumnya.

\section{RUMUSAN MASALAH}

Berdasarkan uraian diatas, maka rumusan masalah yang diambil oleh penulis adalah sebagai berikut:

1. Bagaimanakah kelayakan pembukaan cabang baru dari aspek pemasaran, aspek teknis, aspek keuangan, aspek SDM, aspek lingkungan dan aspek hukum?

2. Bagaimana bentuk layout dari cabang usaha Rumah Makan Kehidupan Tidak Pernah Berakhir di lokasi yang baru?

\section{TUJUAN PENELITIAN}

Berdasarkan rumusan masalah yang telah dibuat maka tujuan dari dilakukannya penelitian ini adalah sebagai berikut:

1. Mengetahui dan menganalisis kelayakan pembukaan cabang baru rumah makan vegetarian dari aspek pemasaran, teknis, keuangan, SDM, lingkungan dan hukum.
2. Mengetahui dan menganalisis bentuk layout yang baik dan dapat direalisasikan pada cabang baru tersebut.

\section{TINJAUAN PUSTAKA}

Aspek-Aspek Analisis Kelayakan

1. Aspek Pasar

Pengkajian aspek pasar penting dilakukan karena tidak ada proyek bisnis yang berhasil tanpa adanya permintaan atas barang atau jasa yang dihasilkan proyek tersebut. Pada dasarnya, analisis aspek pasar bertujuan antara lain untuk mengetahui berapa besar luas pasar dan pertumbuhan permintaan dari produk atau jasa yang bersangkutan. Analisis dapat dilakukan dengan cara deskriptif maupun inferensial, jenis data yang digunakan dapat berupa kuantitatif maupun kualitatif (Umar, 2009).

2. Aspek Pemasaran

Aspek pemasaran ini digunakan untuk mengetahui dan mengelompokkan karakterkarakter dari konsumen serta untuk mempersiapkan strategi apa yang tepat untuk bisnis tersebut. Aspek pemasaran ini terdiri dari segmeting, targeting, positioning dan bauran pemasaran (product, price, place, promotion, people, physical evidence, process) (Umar, 2009).

3. Aspek Teknis

Studi aspek teknis untuk meyakini apakah dari segi pembangunan proyek dan segi implementasi dapat dilaksanakan secara layak atau tidak layak. Aspek teknis terdiri dari analisis tata letak (layout) dan analisis mengenai lokasi usaha tersebut. Perencanaan jumlah barang-barang dalam membangun usaha bisnis hendaknya direncanakan dengan baik agar jumlah barang yang dibeli tidak terlalu banyak sehingga dapat meminimasi penggunaan modal usaha (Umar, 2009).

4. Aspek Finansial

Studi aspek keuangan bertujuan untuk mengetahui perkiraan pendanaan dan aliran kas proyek bisnis, sehingga dapat diketahui layak atau tidaknya rencana bisnis yang dimaksud. Pada umumnya ada beberapa metode yang biasa dipertimbangkan untuk dipakai dalam penilaian aliran kas dari suatu investasi, yaitu metode Net Present Value (NPV), Internal Rate of Return (IRR), Payback Period (PBP), Profitability Index (PI) (Umar, 2009). 
- Net Present Value (NPV) atau Nilai Bersih Sekarang

NPV yaitu selisih antara present value dari investasi dengan nilai sekarang dari penerimaan - penerimaan kas bersih di masa yang akan datang. Untuk menghitung nilai sekarang perlu ditentukan tingkat bunga yang relevan.

Kriteria penilaian :

a. Jika NPV $>0$, maka usulan proyek diterima,

b. Jika NPV $<0$, maka usulan proyek ditolak,

c. Jika NPV $=0$, nilai perusahaan tetap walau usulan proyek diterima maupun ditolak.

- Internal Rate of Return (IRR) atau Tingkat Pengembalian Internal

Metode ini digunakan untuk mencari tingkat bunga yang menyamakan nilai sekarang dari arus kas yang diharapkan di masa datang, atau penerimaan kas, dengan mengeluarkan investasi awal. Kriteria penilaian investasi dengan menggunakan analisis IRR, yaitu:

a. Jika WACC $\geq$ rate of return, maka investasi layak untuk dijalankan.

b. Jika WACC < rate of return, maka investasi tidak layak untuk dijalankan.

- Payback Periode (PBP) atau Masa Pengembalian Investasi

Payback periode adalah suatu periode yang diperlukan untuk menutup kembali pengeluaran investasi (initial cost investment) dengan menggunakan aliran kas, dengan kata lain payback periode merupakan rasio antara initial cash investment dengan cash flow-nya yang hasilnya merupakan satuan waktu.

5. Aspek Sumber Daya Manusia (SDM)

Rencana bisnis yang akan diimplementasikan melalui pembangunan bisnis secara rutin memerlukan kelayakan aspek SDM nya. Dalam aspek Sumber Daya Manusia ini terdiri dari rekrutmen serta job description serta jumlah pekerja yang diperlukan (Umar, 2009).

6. Aspek Lingkungan

Studi aspek lingkungan hidup bertujuan untuk menentukan apakah secara lingkungan hidup, misalnya dari sisi udara dan air, rencana bisnis diperkirakan dapat dilaksanakan secara layak atau sebaliknya (Umar, 2009).

7. Aspek Hukum

Aspek hukum dimaksudkan untuk meyakini apakah secara yuridis rencana bisnis dapat dinyatakan layak atau tidak. Jika suatu rencana bisnis yang tidak layak dapat direalisasikan, bisnis berisiko besar akan dihentikan oleh pihak yang berwajib atau oleh protes masyarakat. (Umar, 2009).

\section{Depresiasi}

Menurut Newnan (2013) depresiasi berari penurunan nilai. Dalam konteks analisis ekonomi. Nilai bisa merujuk kepada nilai pasar. Nilai pasar adalah nilai uang atau properti atau nilai bagi pemilik. Maka dari itu depresiasi memiliki dua arti, yaitu: penurunan pada nilai pasar serta penurunan nilai bagi pemilik. Terdapat berbagai cara menghitung depresiasi, salah satunya adalah straight line depreciation/depresiasi garis lurus.

Depresiasi garis lurus adalah metode perhitungan depresiasi yang paling sederhana dan juga yang paling dikenal. Dengan perhitungan depresiasi metode ini, besarnya depresiasi konstan setiap tahunnya. Besarnya depresiasi dapat dihitung dengan rumus berikut:

$$
\text { depresiasi tahunan }=\frac{1}{N} \times(P-S)
$$

$$
\begin{aligned}
\text { Dimana: } & \mathrm{N}=\text { umur pakai } \\
\mathrm{P} & =\text { harga aset } \\
\mathrm{S} & =\text { nilai buku }
\end{aligned}
$$

\section{MODEL PENELITIAN}

Pada bagian ini berisi tahap - tahap dalam melakukan penelitian, mulai dari penentuan topik sampai menghasilkan kesimpulan dan saran. Gambar 1 merupakan metodologi penelitian analisis kelayakan bisnis pembukaan cabang baru rumah makan Kehidupan. 
Gambar 1. Model Penelitian

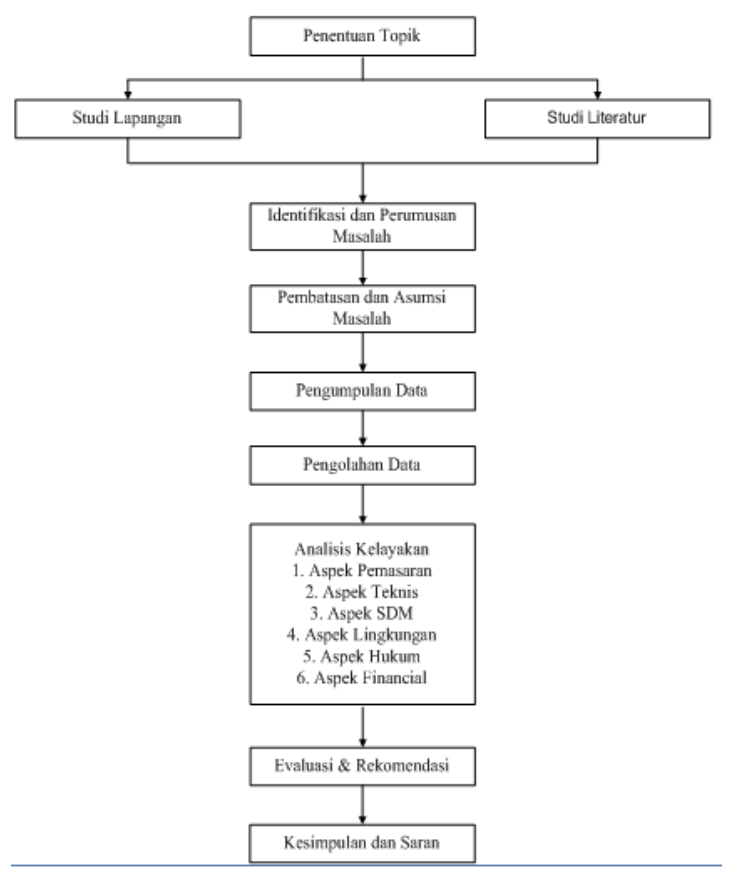

POPULASI DAN SAMPEL

Populasi pada penelitian ini adalah jumlah pengunjung Rumah Makan Kehidupan per hari dan jumlah penduduk di sekitar Buah Batu sebagai lokasi pembukaan cabang baru. Jumlah pengunjung Rumah Makan kehidupan rata-rata per hari adalah 200 orang dengan jumlah sampel yang diambil adalah 132 orang. Sedang jumlah penduduk di sekitar Buah Batu pada tahun 2013 adalah 29.974 orang dengan sampel yang diambil adalah 379 orang.

\section{METODE PENGUMPULAN DATA}

Penelitian ini menggunakan data primer dan sekunder. Data primer yaitu data yang diperoleh langsung dari sumbernya melalui hasil wawancara, seperti jumlah pengunjung per hari rumah makan, ketertarikan masyarakat akan makanan vegetarian. Sedang data sekunder adalah data yang diperoleh dari media elektronik maupun media cetak, seperti jumlah penduduk di Buah Batu, harga-harga peralatan (Sugiyono, 2012).

\section{HASIL DAN PEMBAHASAN}

Penelitian ini akan membahas tentang analisis kelayakan bisnis pembukaan cabang baru Rumah Makan Kehidupan di Buah Batu. Rencana analisis ini meliputi analisis pasar, pemasaran, teknis, SDM, lingkungan, hukum dan keuangan.
Analisis Aspek Pasar

Rata-rata pengunjung di Rumah Makan Kehidupan saat ini adalah sebesar 200 orang per hari. Jumlah tersebut digunakan sebagai populasi dari pengunjung di Rumah Makan Kehidupan saat ini. Menurut Sekaran (2010) dapat diketahui jika populasi sebesar 200, maka akan didapati sample sebesar 132. Dari 132 responden Rumah Makan Kehidupan, didapati bahwa sebanyak 24 responden bersedia untuk hadir jika dibuka cabang baru di Buah Batu. Dari diagram di bawah terlihat bahwa terdapat pasar yang cukup menjanjikan jika dibuka cabang dari Rumah Makan Kehidupan. Dari 24 orang responden yang menjawab bersedia hadir jika dibuka cabang baru, maka akan dianggap sebagai demand awal dari cabang baru Rumah Makan Kehidupan.

Gambar 2. Pie Chart responden hasil kuesioner di rumah makan

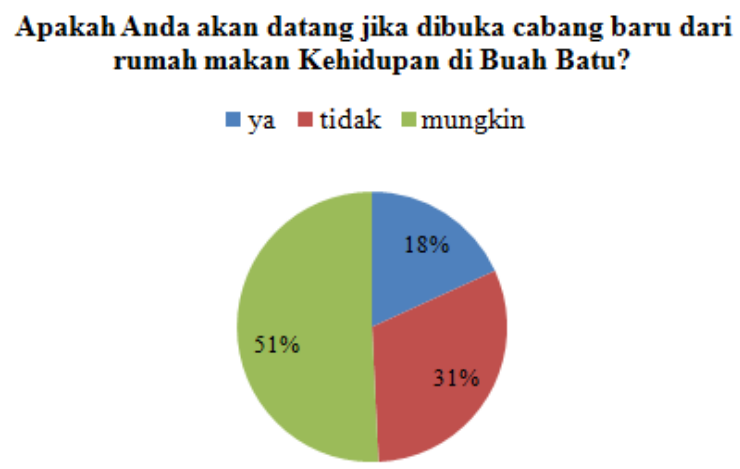

Untuk pengambilan sample di Buah Batu menggunakan teknik nonprobability sampling. Jenis teknik nonprobability sampling yang digunakan adalah teknik sampling aksidental. Sedangkan untuk menentukan jumlah sampel yang harus diambil, maka dilakukanlah perhitungan sampel dengan asumsi tidak diketahui jumlah populasinya. Rumus yang digunakan (Sugiyono, 2012):

$$
n=\frac{Z_{1-\alpha / 2}^{2} \cdot p \cdot(1-p)}{d^{2}}
$$

Dengan menggunakan tingkat keyakinan $(\alpha=$ $5 \%$ ) dan tingkat ketelitian sebesar 5\% (d) serta proporsi nilai $p$ yang digunakan sebesar 0,6 maka perhitungan jumlah sampel yang didapat adalah :

$$
n \geq \frac{1,96^{2} \cdot 0,6 \cdot(1-0,6)}{0,05^{2}}=n \geq 369
$$


Dari hasil perhitungan di atas maka didapatkan nilai $n \geq 369$ yang artinya bahwa penyebaran kuesioner ini minimal dilakukan terhadap 369 responden. Dalam pelakasanaannya peneliti mendapatkan 379 responden dalam penelitian ini, sehingga data yang didapatkan diharapkan lebih mendekati data sesungguhnya.

Gambar 3. Pie Chart responden hasil kuesioner di Buah Batu

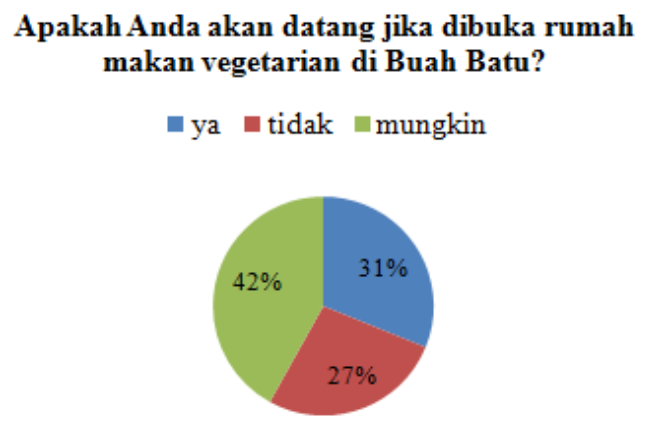

Dari diagram dapat terlihat bahwa terdapat pasar yang cukup besar jika dibuka cabang dari Rumah Makan Kehidupan. Demand awal dari rumah makan cabang ini akan dibagi menjadi dua kondisi yaitu most likely dan pessimstic. Saat kondisi most likely estimasi demand didapat dari jumlah responden yang bersedia hadir dari kuesioner di Rumah Makan Kehidupan saat ini dan kuesioner di Buah Batu, serta ditambah 25\% dari responden yang menjawab mungkin hadir di Buah Batu. Dengan demikian didapati demand awal sebanyak 182 orang $(118+24+40)$ untuk kondisi most likely. Sedangkan saat kondisi pessimstic estimasi demand didapat dari jumlah responden yang bersedia hadir dari kuesioner di Buah Batu dan ditambah 25\% dari responden yang menjawab mungkin hadir di Buah Batu. Dengan demikian didapati demand awal sebanyak 158 orang $(118+40)$ untuk kondisi pessimistic. Untuk kedua kondisi tersebut akan mengalami growth atau pertumbuhan pasar sebesar 5\% setiap tahunnya.

Dari hasil evaluasi segi pasar didapat bahwa permintaan pasar akan Rumah Makan Kehidupan dapat diketahui perkiraannya berdasarkan hasil kuesioner. Demand tersebut masih dapat berkembang / bertambah jika memperhitungkan para responden yang menjawab mungkin hadir. Masakan vegetarian cukup banyak diminati oleh pasar di kota Bandung sehingga pasar yang dituju sudah jelas dan risiko akan kegagalan bisnis menjadi lebih kecil. Oleh karena itu dari segi aspek pasar, bisnis rini dinyatakan layak.
Analisis Aspek Pemasaran

Segmenting

Segmentasi pasar harus dilakukan karena karakteristik konsumen yang biasanya heterogen sehingga menyulitkan Rumah Makan Kehidupan untuk memasuki pasar. Sebaiknya pasar yang ada dibagi-bagi sehingga menghasilkan segmensegmen yang sifatnya homogen. Beberapa aspek utama dalam melakukan segmentasi pasar adalah aspek demografis, psikografis dan juga aspek perilaku.

Targeting

Setelah segmen pasar diketahui, langkah selanjutnya adalah menentukan segmen pasar mana yang akan menjadi target utama dari Rumah Makan Kehidupan. Dalam menentukan target pasar mana yang akan menjadi sasaran utama Rumah Makan Kehidupan harus diperhatikan pula ukuran segmen, pertumbuhan segmen dan juga kemenarikan segmen.

Tabel 1. Targeting Dari Rumah Makan Kehidupan

\begin{tabular}{|l|l|}
\hline Aspek Demografis & $\begin{array}{l}\text { Pria dan wanita; usia di } \\
\text { atas 22 tahun }\end{array}$ \\
\hline Aspek Psikografis & $\begin{array}{l}\text { Masyarakat kelas bawah, } \\
\text { menengah dan atas }\end{array}$ \\
\hline Aspek Perilaku & $\begin{array}{l}\text { Setia dan tidak setia, } \\
\text { mementingkan harga, } \\
\text { kualitas dan pelayanan }\end{array}$ \\
\hline
\end{tabular}

\section{Positioning}

Rumah Makan Kehidupan menawarkan menumenu makanan yang semua bahannya diolah dari bahan nabati. Serta dalam pengolahannya tidak menggunakan MSG dan bawang putih. Banyak variasi menu makanan yang ditawarkan oleh Rumah Makan Kehidupan, selain beragam jenis sayuran, rumah makan ini juga menawarkan menu daging-dagingan. Menu daging-dagingan ini tidak terbuat dari bahan hewani, melainkan tetap menggunakan bahan nabati. Hal inilah yang menjadi keunikan tersendiri dari Rumah Makan Kehidupan. Selain itu dirumah makan ini juga menawarkan menu hidangan dengan nama-nama yang unik, hal tersebut dapat membuat konsumen penasaran untuk mencoba hidangan tersebut. Produk utama dari Rumah Makan Kehidupan adalah menu paketnya. Satu menu paket dihargai dengan Rp6000 saja. Hal inilah yang menarik banyak perhatian masyarakat untuk makan di rumah makan ini. Selain 
harganya yang murah, Rumah Makan Kehidupan juga menawarkan produk yang unik, bersih, sehat dan juga enak.

\section{Product}

Produk utama dari rumah makan ini adalah menu-menu vegetarian atau menu-menu yang semuanya terbuat dari bahan nabati. Terdapat berbagai macam olahan sayuran seperti tempe, tahu, kentang, jamur dan sayur-mayur yang lainnya. Selain itu juga terdapat menu olahan yang menyerupai daging, seperti rendang, ayam goreng, sosis, bahkan mie. Namun semua menu yang disajikan terbuat dari bahan-bahan nabati, kepiawaian dalam mengolah bahan inilah yang menjadi keunikan dari Rumah Makan Kehidupan.

Price

Produk utama rumah makan ini adalah menu paket yang dihargai dengan Rp6000. Hal ini dilakukan manajemen rumah makan untuk memenuhi target pasar mereka, yaitu masyarakat kelas menengah dan bawah. Sedangkan harga menu daging-dagingan dihargai Rp5000, hal ini dilakukan untuk mengimbangi cara pengolahaannya yang lebih susah dibandingkan dengan pengolahan menu paket.

\section{Place}

Rumah Makan Kehidupan saat ini memiliki 2 buah mobil boxs. Mobil tersebut digunakan untuk mengangkut bahan baku yang didatangkan dari Lembang menuju Rumah Makan Kehidupan saat ini di jalan Padjajaran. Selain untuk mengangkut bahan baku mobil ini juga kadang digunakan untuk mengantar pesanan catering ke rumah-rumah pelanggannya. Kedua mobil boxs tersebut tidak semuanya digunakan setiap hari. Jadi jelas bahwa tanggung jawab utama dari sistem distribusi rumah makan ini adalah mengangkut bahan baku serta mengantarkan pesanan dari Rumah Makan Kehidupan.

\section{Promotion}

Untuk saat ini promosi di Rumah Makan Kehidupan hanya menggunakan brosur serta papan nama yang dibuat sedemikian rupa untuk menarik perhatian masyarakat yang lewat. Rumah makan Kehidupan belum menggunakan media iklan yang lain untuk mempromosikan rumah makan ini. Brosur yang digunakan untuk mempromosikan rumah makan ini juga hanya diletakkan di sebelah kasir saja.
People

Dalam hal ini people di Rumah Makan Kehidupan adalah para pelayan dan kasir, karena merekalah yang berinteraksi secara langsung dengan para konsumen. Para pelayan harus dapat melayani para konsumen dengan baik, ramah dan cekatan. Para pelayan harus dapat melayani konsumen dengan baik, artinya bahwa mereka mengerti tugasnya masing-masing dan dapat menjalankannya dengan benar.

\section{Process}

Dalam mengolah menu paket serta menu dagingdagingan, dilakukan oleh koki serta dibantu juga oleh para pelayan. Terdapat dua koki utama di Rumah Makan Kehidupan. Semua bahannya tidak ada yang mengandung unsur hewani, selain itu juga tidak menggunakan MSG, pewarna dan pengawet makanan.

Dari hasil evaluasi segi pemasaran didapat bahwa strategi pemasaran yang dilakukan sudah sesuai dengan target pasar Rumah Makan Kehidupan yang akan didirikan ini. Dengan produk yang ditawarkan makanan sehat dan murah, niscaya orang-orang akan datang dan mau untuk kembali datang ke rumah makan ini. Oleh karena itu dari segi aspek pemasaran, bisnis Rumah Makan Kehidupan cabang Buah Batu diharapakan layak.

Analisis Aspek Teknis

Didalam aspek ini membahas mengenai bagaimana lokasi yang menjadi tempat pembukaan cabang baru ini, apa saja alat-alat yang digunakan, bagaimana layout tata letaknya.

\section{Lokasi}

Lokasi yang dipilih untuk mendirikan cabang Rumah Makan Kehidupan ditentukan oleh peneliti, yaitu di Buah Batu. Hal ini didasarkan berdasarkan hasil kuesioner yang didapati bahwa terdapat sebagain pelanggan Rumah Makan Kehidupan saat ini berasal dari Bandung selatan. Kemudian penentuan lokasi ini dikonfirmasikan kepada pihak Rumah Makan Kehidupan, pihak Rumah Makan Kehidupan lebih memilih lokasi di Buah Batu dibandingkan dengan lokasi lain di Bandung selatan, seperti Soekarno Hatta, Holis maupun Kopo.

\section{Layout}

Layout dari rumah makan disesuaikan dengan bentuk bangunan saat ini. Diperlukan beberapa renovasi untuk menyesuaikan konsep Rumah 
Makan Kehidupan. Terdapat 2 lantai, dimana lantai pertama diperuntukkan untuk dapur, meja saji dan ruang makan. Sedangkan lantai dua diperuntukkan untuk kantor dan ruang makan.

Gambar 4. Layout Lantai 1

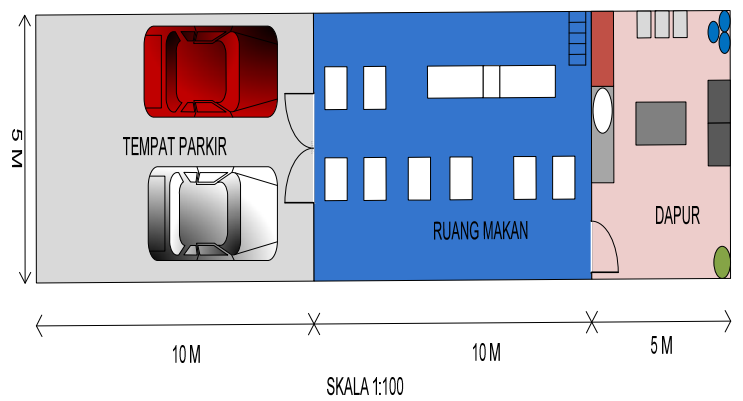

Gambar 5. Layout Lantai 2

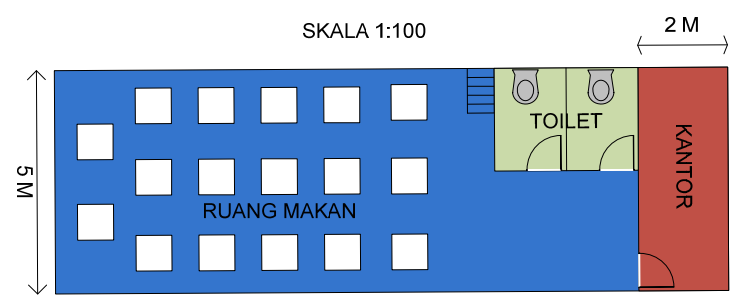

Peralatan

Kebutuhan peralatan harus diperhatikan dalam pengoperasian rumah makan agar bisnis ini dapat berjalan dengan lancar. Peralatan sangat berpengaruh karena bisnis rumah makan menggunakan banyak peralatan, diantaranya: peralatan makan, peralatan dapur, peralatan elektronik serta peralatan lainnya yang dianggap perlu.

Operasional

Rumah makan ini akan dibuka pada pukul 09.00 hingga pukul 22.00. Dibuka pada jam 9 pagi karena disesuaikan dengan jam operasional dari rumah makan Kehidupan saat ini.

Dari hasil evaluasi aspek teknis didapati bahwa lokasi didirikannya rumah makan sudah ada, produk yang ditawarkan jelas, peralatan yang diperlukan sudah didata dan siap untuk dibeli, jam operasional serta layout telah dipertimbangkan. Oleh karena itu dari segi teknis bisnis rumah makan ini dinyatakan layak.
Analisis Aspek SDM

Jabatan yang diperlukan adalah 1 orang kapten, 2 orang koki dan 8 orang pelayan. Suatu bisnis rumah makan tentu saja membutuhkan koki untuk menyiapakan dan memasak makanan bagi konsumen, pelayan diperlukan untuk membantu koki dalam memasak makanan serta untuk melayani konsumen. Kapten diperlukan untuk mengawasi dan membantu kegiatan operasional rumah makan agar berjalan dengan lancar. Pada struktur organisasi untuk rumah makan cabang Buah Batu, kapten yang bertanggung jawab penuh terhadap operasional dari rumah makan, sedang untuk koki dan pelayan memiliki kesetaraan jabatan. Meskipun demikian kapten tetap harus melapor kepada manajer yang bertugas di Rumah Makan Kehidupan saat ini, tanggung jawab dan pimpinan utama berada pada pemilik usaha yang bertempat tinggal di Jakarta.

Dari hasil evaluasi aspek segi sumber daya manusia didapat bahwa struktur organisasi sudah jelas dan didapat seluruh jabatan di rumah makan dapat dicarikan orangnya dengan mudah. Oleh karena itu dari segi teknis bisnis rumah makan ini dinyatakan layak

Analisis Aspek Lingkungan

Dari segi evaluasi aspek lingkungan dapat dilihat sesuai AMDAL bahwa harus adanya pengelolaan berkelanjutan dari sampah yang ada dari bahan makanan dan sisa makanan pelanggan. Sampah ini berbentuk padat dan cair. Di dalam tempat sampah tersebut telah dilapisi dahulu dengan trash bag, hal ini dilakukan untuk mempermudah pada saat pengambilan sampah nantinya. Tempat sampah tersebut juga dilengkapi dengan tutup sehingga bau yang tidak sedap dari sampah tersebut dapat diminimalisasi. Sebelumnya trash bag tersebut diikat dengan rapat sebelum dipindahkan, hal ini dilakukan untuk mengurangi bau tidak sedap yang dapat mengganggu kenyamanan masyarakat sekitar. Setiap pagi dari pihak dinas kebersihan setempat terdapat truck sampah yang akan mengangkut sampah-sampah tersebut. Untuk limbah cair akan dibuang melalui saluran pembuangan lewat pipa-pipa yang akan disalurkan ke dalam selokan yang ada di bawah tanah. Oleh karena itu bau ataupun aliran dari limbah cair ini tidak akan mengganggu karyawan atupun masyarakat sekitar. Jika aspek ini dijalankan dengan baik dan benar makan aspek ini dapat dinyatakan layak.

Analisis Aspek Hukum 
Aspek ini perlu dievaluasi karena untuk membangun sebuah rumah makan diperlukan beberapa surat-surat dokumen-dokumen penting yang harus dibuat dan diperhatikan. Berikut adalah surat-surat yang harus dipenuhi

Tabel 2. Dokumen dan Izin Terpenting Yang Dibutuhkan

\begin{tabular}{ccl}
\hline Dokumen dan izin yang diperlukan & Kemudahan mendapatkannya & \multicolumn{1}{c}{ Kepada } \\
\hline IMB & $\sqrt{ }$ & Dinas Tata Kota dan Tata Bangunan \\
STTU & $\sqrt{ }$ & Pemda Kota Bandung \\
NPWP & $\sqrt{ }$ & Penda Kota Bandung \\
Izin kepada RT/RW & $\sqrt{ }$ & Ketua RT/Ketua RW \\
\hline
\end{tabular}

Oleh karena itu dari segi aspek hukum, jika surat-surat tersebut dapat dipenuhi makan bisnis rumah makan ini layak untuk dijalankan.

Analisis Aspek Keuangan

Terdapat 3 kriteria penilaian investasi yang dilakukan yaitu berdasarkan payback period, $N P V$ dan IRR. Ketiga kriteria penilaian tersebut merupakan acuan didalam menganalisis apakah pembukaan Rumah Makan Kehidupan cabang Buah Batu dapat dinyatakan layak dari aspek keuangan. Masing-masing kriteria penilaian digunakan untuk melakukan penilaian terhadap kondisi most likely maupun kondisi pessimistic.

Tabel 3. Kritera Penilaian Kondisi Most Likely

\begin{tabular}{crr}
\hline Tahun & Arus Kas Bersih & Sisa Investasi \\
\hline 0 & -Rp682.435.660 & -Rp682.435.660 \\
\hline 1 & Rp29.958.209 & -Rp652.477.451 \\
\hline 2 & Rp138.640.834 & -Rp513.836.617 \\
\hline 3 & Rp251.320.157 & -Rp262.516.460 \\
\hline 4 & Rp451.558.638 & Rp189.042.178 \\
\hline 5 & Rp587.210.906 & Rp776.253.084 \\
\hline & PBP & 3.6 tahun \\
\hline & NPV & Rp356.199.505 \\
\hline
\end{tabular}

Tabel 4. Kriteria Penilaian Kondisi Pessimistic 76

\begin{tabular}{crr}
\hline Tahun & Arus Kas Bersih & \multicolumn{1}{l}{ Sisa Investasi } \\
\hline 0 & -Rp652.381.420 & -Rp652.381.420 \\
\hline 1 & -Rp23.853.731 & -Rp676.235.151 \\
\hline 2 & Rp67.084.713 & -Rp609.150.438 \\
\hline 3 & Rp160.789.678 & -Rp448.360.759 \\
\hline 4 & Rp330.965.412 & -Rp117.395.347 \\
\hline 5 & Rp443.374.813 & Rp325.979.466 \\
\hline & PBP & 4,3 tahun \\
\hline & NPV & Rp45.177.370 \\
\hline & IRR & $10 \%$ \\
\hline
\end{tabular}

Dari tabel dapat dilihat bahwa nilai NPV sudah diatas angka 0, sehingga berdasarkan NPV dapat dinyatakan layak. Begitu pula dengan penilaian investasi menggunakan IRR yang menyimpulkan kondisi tersebut layak karena memiliki nilai lebih besar dari WACC yang sebesar $8,25 \%$. Untuk penilaian investasi berdasarkan PBP pada kondisi pessimistic, pengembalian modal akan didapat setelah 4 tahun. Namun dari penilaian investasi berdasarkan PBP bergantung dari subjektivitas pelaku bisnis untuk pengembalian modal selama itu layak atau tidak.

\section{KESIMPULAN}

Kesimpulan yang diperoleh dari penelitian ini adalah sebagai berikut:

1. Pembukaan cabang baru Rumah Makan Kehidupan ini layak dijalankan dari aspek pasar, kelayakan ini dinilai dari jumlah estimasi produk yang dapat dijual di rumah makan cabang Buah Batu.

2. Dari aspek pemasaran, bisnis ini layak dijalankan karena dari analisis STP dan 7P menunjukkan bahwa target pasar yang disasar oleh rumah makan cabang Buah Batu dapat diambil.

3. Dari aspek teknis bisnis ini layak dijalankan karena lokasi dan alat-alat yang diperlukan untuk menjalankan bisnis ini dapat dipenuhi dengan baik.

4. Dari aspek sumber daya manusia, bisnis ini layak dijalankan karena kemudahan dalam mendapatkan sumber daya manusianya.

5. Berdasarkan studi kelayakan aspek hukum, bisnis ini dinyatakan layak karena kemudahan mendapatkan dokumen-dokumen serta izin-izin yang dibutuhkan dalam mendirikan rumah makan.

6. Bisnis Rumah Makan Kehidupan cabang Buah Batu dikatakan layak dari segi lingkungan, karena telah ditemukan adanya 
pengelolaan sampah yang dihasilkan pada bisnis ini, baik pengolahan sampah padat maupun cair.

7. Dari aspek keuangan bisnis ini dinyatakan layak, hal ini dapat dilihat pada hasil penilaian investasi berdasarkan NPV, IRR dan PBP.

8. Pelaku bisnis perlu melaksanakan manajemen operasional dengan sebaik mungkin karena faktor eksternal dan internal sangat mendukung terkait pembukaan cabang baru Rumah Makan Kehidupan di Buah Batu.

\section{Keterbatasan Penelitian}

Pada penelitian ini terdapat beberapa batasan, tujuan dari batasan tersebut adalah agar penelitian ini tetap terfokus dan tidak menjadi terlalu luas. Berikut ini adalah beberapa batasan yang terdapat pada penelitian ini :

1. Lokasi yang diteliti hanya di kota Bandung saja.

2. Aspek yang digunakan hanya aspek pemasaran, aspek teknis, aspek keuangan, aspek SDM, aspek lingkungan dan aspek hukum.

\section{Saran}

Saran yang dapat diberikan, yaitu:

1. Pelaku bisnis sebaiknya meningkatkan harga jual sesuai dengan tingkat inflasi yang terjadi tiap tahunnya.

2. Pelaku bisnis juga sebaiknya mengadakan evaluasi kinerja perusahaan secara rutin, sehingga dapat terlihat apabila ada kekurangan-kekurangan yang harus diperbaiki.

3. Penelitian ini hanya membahas 7 aspek sehingga tidak menutup kemungkinan untuk melakukan studi berdasarkan aspek-aspek yang lain, seperti aspek teknik dan teknologi, aspek manajemen, aspek sosial dan politik serta aspek lingkungan industri.

\section{REFERENSI}

Newnan, D. G. (2013). Engineering Economic Analysis. Jakarta : Binarupa Aksara.

Sekaran, U. (2010). Research Methods For Business. Michigan: Wiley India.
Sugiyono. (2012). Statistika untuk Penelitan. Bandung: CV Alfabeta.

Umar, H. (2009). Studi Kelayakan Bisnis: Teknik Menganalisis Kelayakan Rencana Bisnis Secara Komprehensif. Jakarta: PT Gramedia Pustaka Utama. 
Jurnal Manajemen Maranatha — Vol. 18 Nomor 1, November (2018) 